\title{
From Academic Publications and Patents to the Technological Development of the Economy: Short and Long Run Causalities
}

\author{
DOI: 10.12776/QIP.V23I1.1166 \\ Marta Orviská, Ján Huňady, Peter Pisár, John Hudson
}

Received: 23 September 2018 Accepted: 19 December 2018 Published: 31 March 2019

\begin{abstract}
Purpose: The paper examines the potential effects of academic publications on patenting and the share of high technology exports. We test the short-run and the long-run causalities among high technology exports, the number of academic publications and the number of patents in three separate models.
\end{abstract}

Methodology/Approach: Our sample consists of panel data for 61 countries and 20 years. The panel Granger causality and vector error correction model have been used in order to capture the short-run causalities. Furthermore, panel cointegration regressions have been applied to test for long-run causalities.

Findings: Our results strongly suggest that there is a positive long-run effect of academic publications on both patenting and the share of high technology exports. This suggests that the outcomes of basic science in the form publications strongly support technological development, and thus emphasises the importance of basic research. In addition the effect of patents on high technology exports is mostly insignificant when controlling for academic publications and GDP.

Research Limitation/implication: First, the variables used in the analysis are only proxies. The scope of the data has been significantly limited by the data availability. This leads also to limited the number of control variables.

Originality/Value of paper: There are still only a very limited number of studies testing the effect of academic outcomes on the technological development of the economy. Our research brings new empirical insights into this problem.

Category: Research paper

Keywords: academic research; academic publication; patent; technological development; high-technology exports 


\section{INTRODUCTION}

The technological development of the economy is mostly seen as one of the most important or even the most important determinant of sustainable economic growth. Keys to this are technical change and innovation. Our perceptions of these processes have developed considerably since the early work of Solow (1957) a critical change has been the emergence of endogenous growth models. According to one version of the endogenous growth model, technological progress is generated in research and development (R\&D). As reported by Anselin, Varga and Acs (1997) the accumulation of knowledge and its spillover into productive capacity through technological change is a central theme in the new theory of endogenous growth. They stated that universities play an important role in this process, in the role of producers of basic research, as well as by creating human capital. In our research we take into account the scientific outputs of all knowledge producers. However, we are predominantly applying our results on universities. In our research we take into account the data capturing the scientific outputs of all knowledge producers, but we are predominantly applying our findings to universities. However, universities are the main knowledge producers only in some countries. They are mostly the key knowledge producers with respect to outputs of basic science. Universities also play a central role in models such as the triple helix, which evolved out of earlier work done on National Innovation Systems (NIS) (Freeman, 1987; Lundvall, 1992, and Nelson, 1993). The NIS views innovation within nations as revolving around the interactions of companies, universities and research institutes. Their activities are governed by institutions, particularly public sector institutions and this is one way governments can stimulate interaction between learning and knowledge transfer, leading to successful innovation. It emphasises the role universities play in research, $\mathrm{PhD}$ and other training, and technology transfer (Mowery and Sampat, 2004). Such interaction between academia and industry is often done within the context of science parks (Minguillo and Thelwall, 2015). The Regional Innovation Systems (RIS) concept evolved from that of the NIS. To an extent this is similar to NIS, but on a smaller scale. However, with a regional focus it emphasises the importance of spatial proximity, which is particularly important with respect to tacit knowledge which requires face to face interactions (Asheim and Gertler, 2005).

In some cases, knowledge is transferred to the private sector via university industry collaboration in publishing (Lebeau et al., 2008). On occasion too, the knowledge transfer to the firm is direct as the academic turns entrepreneur. Thus it is not uncommon for academics, or at least their universities, to do the patenting (Czarnitzki, Glänzel and Hussinger, 2007). Despite this, the mechanism on exactly how the university-industry linkage facilitates innovation is only imperfectly understood and there has, e.g., been only relatively few studies which look at the dynamics of NIS and RIS (Perkmann et al., 2013). This is a gap which this paper is focused on at least partially filling. We are especially focused on the impact of basic research, and estimate the potential long-run effect of academic 
outputs on the technological development of the economy. We thus use the number of academic publications in selected journals as the proxy for scientific output. This variable was specifically used as there seems to be some growing doubts about the impact of this kind of research outcome on the real economy (Castellacci and Natera, 2013). Moreover, we also take into account the number of patents. To some extent patents could be seen as another kind of scientific output, but in a more applied form. On the other hand, patents are often used as a proxy for inventions, as for example by Artz et al. (2010). They can then be seen as the first step towards innovation. We believe that academic publications can be seen more as the output of basic research and create an important basis for invention and innovation. On the other hand patents are one step further down the line towards innovation and technological development (Breschi, Lissoni and Montobbio, 2005).

The main aim of the paper is to test the potential causalities between academic publications, the number of patents and the share of high technology exports controlling for endogeneity. We proxy the technological level of the economy by the high technology exports share in total exports. The link between these two has previously been noted in the literature by, e.g., Montobbio and Rampa (2005). Castellacci and Natera (2013) are one of few authors who looks at the dynamics of NIS. There are still only a very limited number of studies testing the effect of academic outcomes on the technological development of the economy in the long-run. In our analysis, a macroeconomic perspective on this problem is applied, despite the fact that we are aware of the importance of certain processes which are more at the micro level, e.g. at the level of universities, research organizations and companies.

In the next section of our paper we review the most suitable literature sources which have been published in this field so far. In the third section we describe the data and methodology used in the analysis. The methodology part is followed by the presentation and discussion of the most important results and the paper ends with the conclusions.

\section{LITERATURE REVIEW}

As argued by Bercovitz and Feldmann (2006), universities are often viewed as engineers of economic growth as well as regional technological development and revitalization. However, the process of university-led development could take considerable time and energy that is often outside of the immediate interests of the political processes (Bercovitz and Feldman, 2006). Despite the indisputable role of universities as knowledge producers, there is still a growing pressure on universities to apply that knowledge in closely cooperating with industry and government in the development of innovation. This is in line with the triple helix model, where the relationships between universities, industry and government are the key factors for innovation and further technological development (Etzkowitz and Leydesdorff, 2000). However, in fact there are still relatively large 
differences among sectors of the economy. As argued by Stankevice and Jucevicius (2013) collaboration with universities is much more important for high-technology companies than service companies, which are more reliant on other agents such as clients, suppliers and external consultants when developing innovation. The argument is that the high technology companies are more dependent upon intellectual property and the external sources that can generate it. Maglio et al. (2006) have also suggested that links between the service sector and academia are relatively weak. In addition high technology areas of the service sector are likely to co-operate with partners, although less so with universities, than high technology manufacturing (Tether, 2002).

Based on the concept of open innovation introduced by Chesbrough (2006), the universities are seen in the context of innovation as external sources of information. This kind of information tends to be more often used by companies compared to internal R\&D. In order to facilitate the flow of information there is a need for more intensive scientific openness. McMilla, Mauri and Casey (2014) measured scientific openness by the number of academic publications. They found that academic publications are a good predictor of both positive technological changes at the level of firms and appear to have an effect also on the scientific outcomes of firms, measured by the number of times an individual firm's patents cite the scientific literature. The findings of Herrera, MuñozDoyague and Nieto (2010) confirm that scientific knowledge provided by public researchers has a significantly positive effect on both inputs and outputs of the firms' innovation process. The authors emphasized the importance of access of firms to additional knowledge which is complementary to that which they already hold, and often leads to practical application of this knowledge.

Thomas, Sharma and Jain (2011) stated that academic publications are one of the most common indicators that can be used as a proxy for academic productivity and excellence. Nguyen and Pham (2011) examined the effect of scientific articles on a knowledge based economy index. They analysed articles published in international peer reviewed journals between 1991 and 2010 in East Asian countries. They found that at the country level, the correlation between a knowledge based economy index and academic publications was 0.94. The authors concluded that the results suggested the existence of a strong relationship between academic research and the degree of "knowledgization" of the economy. Another indicator used in analysis is the number of patents. In general patents have been accepted as indicators of $R \& D$ processes and even though not all inventions are patented and not all patents are profitable, they have become the most common indicator of innovative output (Thomas, Sharma and Jain 2011). Zachariadis (2003) argues that R\&D expenditure is mostly reflected in the number of patents, and patents have a positive effect on the development of technologies which raises economic growth. A similar effect of patents on growth is also shown by Hudson and Minnea (2013). The positive effect of university $\mathrm{R} \& \mathrm{D}$ on patents has been previously found, for example by Jaffe (1989). Moreover, Stephan et al. (2007), as well as Carayol and Matt (2004) both 
found a positive correlation between academic outputs, as measured by publications, and the number of patents.

There are several ways in which patenting and academics are related together. On the one hand, firms with access to academic research have been shown to enhance their patent performance. This is particularly true for younger firms (Soh and Subramanian, 2014). On the other hand universities can apply for their own patents based on their research activities. Appling for a patent by universities could be an effective way to commercialize the results of their research to a certain extent. Veugelers et al. (2012) map the presence and impact of universities on development of technology. They analyse the number of patents applied for by universities and found that academically owned patents are more commonly used by firms in the US than in European countries. This may be related to the so-called European paradox, which describes the phenomenon that EU countries play a leading role in terms of top-level academic output, but still lag behind in the ability of converting these results into wealth-generating innovations in the business sector (Czarnitzki, Hussinger and Schneider, 2012).

Apart from the triple helix model, work on NIS and RIS also paved the way for the university engagement approach (Chatterton and Goddard, 2000). The concept of the engaged university explicitly emphasises a strong regional focus in their teaching and research activities. As suggested by the related concept of the 'entrepreneurial university', universities are to take a proactive role in this process and thus in regional development. Such universities are not only entrepreneurial in terms of technology development, but also respond to the needs of the region (Chatterton and Goddard, 2000). They play a 'developmental' role by building institutions and facilitating networks which facilitate the regions they are located within (Gunasekara, 2006). The mechanism by which the university industry linkage facilitates innovation is only imperfectly understood. Considerable work has been done on commercialisation (Perkmann et al, 2013). Castellacci and Natera (2013) in a panel cointegartion analysis of 98 countries over a 29 year period found that the dynamics of NIS are driven by the coevolution of technological output, academic output and innovative input on the one hand, and per capita income, infrastructures and international trade, on the other. Surprisingly they found a negative relationship between scientific and technological output. This is one of the relatively few studies which has looked at the dynamics of NIS. Thus overall a great deal of work has been written which assumes universities play a critical role in innovation. But there has been much less empirical work which supports this view. 


\section{DATA AND METHODOLOGY}

In our analysis we are testing the assumed long-run and short-run causalities between science, patenting and high technology exports. We are focused on the output side, which means in the case of universities we take into account the number of publications, for patenting it is the number of patents. On one hand we assume that a higher intensity of academic activity could have a positive effect on patenting, which could be interpreted as innovation itself or could foster innovation (as reported for example by Zachariadis; 2003). On the other hand, academic publications could have also a positive influence on technological development by many other ways apart from the patenting path. The number of publications can also be seen as a proxy for scientific openness as applied for example by McMillan, Mauri and Casey (2014). Scientific openness is one of the key determinates of technological development. It is rational to assume that all these effects are likely to be significant in the long-run rather than in short-run. Hence, in order to verify these assumed causalities, we examine potential longrun as well as short-run relationships between the number of academic publications, the number of registered patents and the high-technology exports share.

The intensity of scientific activity of academia could be represented by several different indicators. However, we decided to apply the number of scientific articles as an appropriate proxy. We take into account only scientific articles covered by the Science Citation Index (SCI) and the Social Sciences Citation Index (SSCI), published in the following fields: physics, biology, chemistry, mathematics, clinical medicine, biomedical research, engineering and technology, and earth and space sciences. The number of scientific articles is calculated per 100,000 residents of the relevant country in each period. Similarly, the number of patents is calculated per 100,000 inhabitants. We consider only those patent applications for which the first-named applicant or assignee is a resident of the state concerned. As already discussed, the share of hightechnology exports of manufactured exports was used as the proxy for the technological level of the economy. Based on an assessment of available data, this variable appears to be the most suitable for our purposes. All variables used in regression models are summarized and described in Tab. 1. 
Table 1 - Variables Used in the Regression Models (World Bank database)

\begin{tabular}{|l|l|}
\hline $\begin{array}{l}\text { Variable } \\
\text { (abbreviation) }\end{array}$ & Description \\
\hline $\begin{array}{l}\text { High-tech export } \\
\text { (HTEshare) }\end{array}$ & $\begin{array}{l}\text { High technology exports (as \% of manufactured exports) } \\
\text { High-technology exports are products with high R\&D intensity, such as } \\
\text { in aerospace, computers, pharmaceuticals, scientific instruments, and } \\
\text { electrical machinery. The method for determining high-technology } \\
\text { exports was developed by the Organisation for Economic Co-operation } \\
\text { and Development in collaboration with Eurostat. It takes a "product } \\
\text { approach" based on R\&D intensity (expenditure divided by total sales) } \\
\text { for certain groups of products. }\end{array}$ \\
\hline $\begin{array}{l}\text { Scientific articles } \\
\text { per capita } \\
\text { (SApc) }\end{array}$ & $\begin{array}{l}\text { Number of scientific articles per capita } * 100,000 \\
\text { The number of scientific and engineering articles published by authors } \\
\text { from a certain country in the following fields: physics, biology, } \\
\text { chemistry, mathematics, clinical medicine, biomedical research, } \\
\text { engineering and technology, and earth and space sciences per capita } \\
\text { (considering only articles from a set of journals covered by Science } \\
\text { Citation Index and Social Sciences Citation Index) }\end{array}$ \\
\hline $\begin{array}{l}\text { Patents per capita } \\
\text { (PATpc) }\end{array}$ & $\begin{array}{l}\text { Number of resident patents per capita } * 100,000 \\
\text { Resident patent applications are those for which the first-named } \\
\text { applicant or assignee is a resident of the State concerned. Patent } \\
\text { applications are worldwide patent applications filed through the Patent } \\
\text { Cooperation Treaty procedure or with a national patent office. }\end{array}$ \\
\hline $\begin{array}{l}\text { GDP per capita } \\
\text { GDPpc) }\end{array}$ & $\begin{array}{l}\text { GDP per capita (at price purchasing power parity - PPP) } \\
\text { (in international dollars) }\end{array}$ \\
\hline
\end{tabular}

We also intended to apply foreign direct investment (FDI) inflows as a dependent variable, because we assume that there is some spill-over effect of FDI for the development of the country. FDI can be also seen as one of the carriers of knowledge from developed regions to less developed regions. However, based on the results of panel stationarity tests this variable is very likely stationary at its level, thus we should not use cointegration analysis in this case.

There are several significant outliers in the case of patents, scientific articles as well as GDP per capita. These variables have rather high variability and right skewed distribution. In order to partly eliminate all mentioned problems we used logarithm transformation of these variables in regression models. This also allows us to keep proportionality with the share of higher tech exports which is. Due to transformation we indicate proportional changes rather than unite changes, which is much better in our case due to significant differences between countries. The regression coefficients can be also interpreted as semi-elasticity or elasticity. It is likely that increase in research outputs can have stronger impact on technology development in countries with developed research infrastructure and previous success in basic and applied research. 
We assume that the number of scientific articles could have a positive effect on the patenting and the high-technology export share of total exports. Hence the equations we will be estimating are:

$$
\begin{gathered}
\text { HTEShare }_{i t}=f\left[\log \left(S A p c_{i t}\right),\left(G D P p c_{i t}\right)\right], \\
P A T p c_{i t}=f\left[\log \left(S A p c_{i t}\right),\left(G D P p c_{i t}\right)\right],
\end{gathered}
$$

where HTEshare is the share of high technology exports, SApc is scientific articles per capita, GDPpc is GDP per capita and PATpc is the number of patents per capita.

We will then add to the right hand side variables, academic articles per capita and patents per capita. Wu used especially fully modified ordinary least square (FMOLS) and dynamic ordinary least square (DOLS) in order to estimate longrun causalities. In the case of short-run effects we applied vector error correction model (VECM). All estimation techniques are in more detail described in the text.

Our dataset consists of panel data, thus all variables include a cross-sectional (country) dimension as well as a time dimension. It includes the data for 61 countries in the period 1993-2012. The list of all countries can be seen in Tab. 2. Our aim is to include, as well as more developed countries, developing and poor countries in the sample if possible. Despite this, the data from these countries are often less available, thus most of the countries included in our dataset are developed countries. Due to several missing observations, we get a slightly unbalanced panel with a maximum of 1,220 observations. If there was only one missing observation for a certain country, it was substituted by the arithmetic average of the observations ahead and behind this observation (together 18 values have been obtained this way for all variables).

\begin{tabular}{|c|c|}
\hline EU C & Other Countries \\
\hline 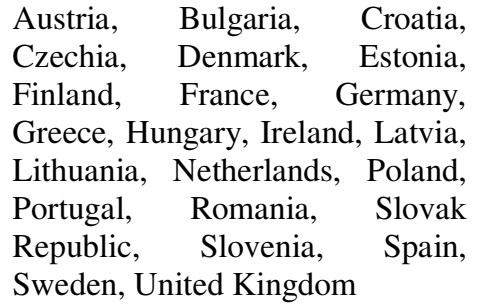 & $\begin{array}{l}\text { Algeria, Australia, Brazil, Canada, Chile, China, } \\
\text { Colombia, Ecuador, Egypt, Guatemala, Iceland, India, } \\
\text { Indonesia, Israel, Jamaica, Japan, Korea Rep., } \\
\text { Macedonia, Madagascar, Malaysia, Mexico, Moldova, } \\
\text { New Zealand, Norway, Pakistan, Peru, Philippines, } \\
\text { Russian Federation, Saudi Arabia, Singapore, South } \\
\text { Africa, Sri Lanka, Switzerland, Thailand, Turkey, } \\
\text { Ukraine, United States, Uruguay }\end{array}$ \\
\hline
\end{tabular}

Table 2 - The List of Countries in the Dataset

Nevertheless, in the case of scientific publications, there were missing observations for all countries in the year 2012. Thus in all models, where this variable was used the period dimension was reduced to 19 years (1993-2011). 
For every other model, the dataset with a 20 years' time frame was applied. The basic descriptive statistics for the three main variables used in our analysis are summarized in Tab. 3.

Table 3 - The Basic Descriptive Statistics of the Main Variables Used in the Models

\begin{tabular}{|l|c|c|c|}
\hline & HTEshare & SApc & PATpc \\
\hline Mean & 13.60 & 29.42 & 18.20 \\
\hline Std. Dev. & 13.56 & 33.61 & 43.18 \\
\hline Observations & 1,204 & 1,152 & 1,210 \\
\hline
\end{tabular}

In the first step of the analysis we test for weak stationary and the order of integration for all variables, which we want to use in the cointegration model. We used the Levin, Lin and Chu (2002), Im, Pesaran and Shin (2003) and Breitung (2000) tests as well as the Fisher ADF and PP tests defined by Choi (2001) and Maddala and $\mathrm{Wu}$ (1999). After we managed to satisfactorily demonstrate the same level of integration by unit root tests, we tested for the existence of cointegration by panel cointegration tests. Cointegration between the dependent and independent variables has been tested for using panel cointegration tests developed by Pedroni (2004) and Kao (1999), which are both widely used in the empirical literature. Both are testing the null hypothesis of no cointegration between selected variables. The Pedroni (2004) cointegration tests use seven different statistics. Four of them are panel cointegration statistics based on the within approach and three of them are group-mean panel cointegration statistics which are based on the between approach. Kao (1999) tests the null hypothesis that the residuals from the estimation are non-stationary.

Obviously, the panel cointegration tests allow us to identify the presence of cointegration, but cannot by itself estimate any long-run coefficients. For this purpose we use panel cointegrated regression models. The long run parameters are estimated by the fully modified OLS (FMOLS) and the dynamic OLS (DOLS) panel cointegration estimators. Both types of estimators have been used in their two forms referred to as a pooled estimator and group-mean estimator. While pooled estimators are based on the "within dimension" of the panel, the group-mean estimators are based on the "between dimension of the panel". The pooled FMOLS estimator is proposed in Phillips and Moon (1999) and the group-mean FMOLS estimator is developed by Pedroni (2000). The pooled DOLS estimator is introduced by Kao and Chiang (2000) and the concept of the group-mean estimator is extended from FMOLS to DOLS by Pedroni (2001). We now briefly describe the essence of the FMOLS and DOLS estimators. 
Both FMOLS and DOLS are based on standard OLS considering the simple fixed-effects panel regression model that can be written as:

$$
Y_{i t}=\alpha_{i}+\beta_{i} X_{i t}+u_{i t}, i=1, \ldots, N, t=1, \ldots, T
$$

where $Y_{i t}$ is a vector of dependent variable and $\beta$ is a vector of coefficients. $\alpha_{i}$ is an individual fixed effect and $u_{i t}$ are stationary disturbance terms. It is assumed that $X_{i t}$ are integrated processes of order one for all $i$. The FMOLS estimator then is written as follows:

$$
\hat{\beta}_{F M O L S}=\left[\sum_{i=1}^{N} \sum_{t=1}^{T}\left(x_{i t}-\bar{x}_{i}\right)^{\prime}\right]^{-1}\left[\sum_{i=1}^{N}\left(\sum_{t=1}^{T}\left(x_{i t}-\bar{x}_{i}\right) \hat{y}_{i t}^{+}+T \hat{\Delta}_{\epsilon \mu}^{+}\right)\right]
$$

where $\hat{\Delta}_{\epsilon \mu}^{+}$is a serial correlation term that gives the covariance matrix of the residuals corrected for autocorrelation and $\hat{y}_{i t}^{+}$is the transformation of the dependent variable $y_{i t}$ in order to achieve the endogeneity correction.

The DOLS estimator is obtained from the following equation:

$$
y_{i t}=\alpha_{i}+\beta x_{i t}+\sum_{j=q_{1}}^{q_{2}} c_{i j} \Delta x_{i, t+j}+u_{i t}
$$

where $c_{i j}$ is the coefficient relating to the leads and lags of the first differenced independent variables. We can estimate $\beta$, the long run coefficient, by the following equation:

$$
\hat{\beta}_{D O L S}=\sum_{i=1}^{N}\left[\sum_{t=1}^{T} z_{i t} z_{i t}{ }^{\prime}\right]^{-1}\left[\sum_{t=1}^{T} z_{i t} \hat{y}_{i t}^{+}\right]
$$

where $z_{i t}=\left(x_{i t}-\bar{x}_{i}, \Delta x_{i t-q}, \ldots, \Delta x_{i t+q}\right)$ is a $2(q+1) \times 1$ vector of regressors.

Both estimators are robust with respect to the potential problems of serialcorrelation and endogeneity, which are potential problems with common ordinary least squares panel data estimators. The FMOLS estimator solves this by nonparametric corrections, while the DOLS estimator uses parametric correction, in effect adding leads and lags of differenced regressors into the regression.

In the final step of the analysis we estimate a panel vector error correction model (VECM) using the residuals from the FMOLS cointegration equation as an error correction term (ECT). While cointegration coefficients reflect the long run balanced relationship, the VECM model is also able to capture the correcting mechanism of short term deviations from long run equilibrium. Thus, this approach is suitable to identify the sort-run effects, while taking into account the long-run relationship between variables. The speed of adjustment to long-run equilibrium can also be estimated by the error correction term coefficient. We 
used the lagged residuals derived from the FMOLS cointegrated regression as error correction terms.

\section{RESULTS}

First of all we apply the panel stationary test as stated in the methodology part. The results of these stationarity tests are summarized in the Appendix at the end of the paper. Based on the majority of the results we can say that all variables except FDI inflows seem to be non-stationary at their level and stationary at their first differences. Thus they are all integrated of the same order, I(1). Hence, we can apply cointegration tests on them. However, we have to exclude the FDI inflows variable from our analysis in this point. In order to test the potential short-run causalities we perform panel Granger causality tests. The results are shown in Tab. 4.

As can be seen there are some indications that the short run effect runs from the number of scientific articles per capita to the number of patents per capita. However, when taking into account the optimum number of lags based on the Schwarz criterion (SBC), which is four in this case, the effect becomes insignificant. Furthermore, there is no evidence for Granger causality between patents and high tech exports. Thus, this kind of effect is not significant at least in the short-run according to our results. On the other hand, the results indicate a statistically highly significant effect of scientific articles on high technology exports share, when considering four lags, which is again the optimum according to Schwarz criterion. This could be interpreted as short-run causality in the Granger sense.

Table 4 - Results of Pairwise Panel Granger Causality Tests

\begin{tabular}{|l|c|c|c|c|}
\hline Number of Lags & Lag =1 & Lag =2 & Lag =3 & Lag =4 \\
\hline H0: $\triangle$ SApc does not Granger cause $\triangle$ PATpc & $3.19^{*}$ & $3.73^{* *}$ & $2.40^{*}$ & 1.61 \\
\hline H0: $\triangle$ PATpc does not Granger cause $\triangle$ SApc & 1.15 & 0.40 & $2.35^{*}$ & 0.79 \\
\hline Observations & 1018 & 956 & 894 & 832 \\
\hline H0: $\triangle$ PATpc does not Granger cause $\triangle$ HTEshare & 2.57 & 1.90 & 1.28 & 0.91 \\
\hline H0: $\triangle$ HTEshare does not Granger cause $\triangle$ PATpc & 0.63 & 1.20 & 1.27 & 1.95 \\
\hline Observations & 1063 & 1000 & 937 & 874 \\
\hline H0: $\triangle$ SApc does not Granger cause $\triangle$ HTEshare & 1.08 & 0.65 & $2.35^{*}$ & $3.11^{* *}$ \\
\hline H0: $\triangle$ PATpc does not Granger cause $\triangle$ HTEshare & 0.19 & 1.17 & 0.83 & 1.71 \\
\hline Observations & 1,011 & 950 & 889 & 828 \\
\hline
\end{tabular}

Notes: $* / * * / * * *$ means significance at the $10 \% / 5 \% / 1 \%$ levels. 
In the next part of the analysis we focus our attention on the long-run causalities. We test for the existence of cointegration among selected variables using the panel cointegration tests described in the methodology part. The results of these tests are summarized in Tab. 5 and Tab. 6. As can be seen in the upper half of the Tab. 5, based on most of the tests we can reject the null hypothesis of no cointegration between high technology exports, academic publications per capita and GDP per capita. Thus, the results are in line with the outcomes of the stationarity tests performed earlier. Similar results can be seen in the lower half of Tab. 5, where we test the null hypothesis of no-cointegration between the number of patents per capita, scientific articles per capita and GDP per capita. Again the results imply the rejection of this null hypothesis, so we can conclude that these variables are cointegrated.

Table 5 - The Results of Cointegration tests

\begin{tabular}{|c|c|c|c|}
\hline \multicolumn{4}{|c|}{ Cointegration: HTEshare; SApc; GDPpc (intercept) } \\
\hline \multicolumn{2}{|c|}{ Null Hypothesis: no cointegration } & Statistic & \\
\hline \multirow{7}{*}{$\begin{array}{l}\text { Pedroni test } \\
\text { (Engle-Granger } \\
\text { based) tests - } \\
\text { individual } \\
\text { intercept, lag } \\
\text { length selection } \\
\text { based on SBC }\end{array}$} & Panel v-Statistic (within dimension) & 0.07 & -0.38 \\
\hline & Panel rho-Statistic (within dimension) & 1.38 & -0.31 \\
\hline & Panel PP-Statistic (within dimension) & $-1.59 *$ & $-5.12 * * *$ \\
\hline & Panel ADF-Statistic (within dimension) & $-5.72 * * *$ & $-8.10 * * *$ \\
\hline & Group rho-Statistic (between dimension) & 3.04 & \\
\hline & Group PP-Statistic (between dimension) & $-3.83 * * *$ & \\
\hline & $\begin{array}{l}\text { Group ADF-Statistic (between } \\
\text { dimension) }\end{array}$ & $-7.27 * * *$ & \\
\hline Kao coint. test & ADF-Statistic & \multicolumn{2}{|c|}{$-4.11 * * *$} \\
\hline \multicolumn{4}{|c|}{ Cointegration: HTEshare; SApc; GDPp (intercept \& trend) } \\
\hline \multicolumn{2}{|c|}{ Null Hypothesis: no cointegration } & Statistic & $\begin{array}{l}\text { Weighted } \\
\text { Statistic }\end{array}$ \\
\hline \multirow{7}{*}{$\begin{array}{l}\text { Pedroni tests } \\
\text { (Engle-Granger } \\
\text { based) - } \\
\text { individual } \\
\text { intercept \& } \\
\text { trend, } \\
\text { lag length } \\
\text { selection based } \\
\text { on SBC }\end{array}$} & Panel v-Statistic (within dimension) & -0.36 & -3.79 \\
\hline & Panel rho-Statistic (within dimension) & 1.23 & 1.73 \\
\hline & Panel PP-Statistic (within dimension) & $5.20 * * *$ & $-7.24 * * *$ \\
\hline & Panel ADF-Statistic (within dimension) & $-8.08 * * *$ & $-10.67 * * *$ \\
\hline & Group rho-Statistic (between dimension) & 4.56 & \\
\hline & Group PP-Statistic (between dimension) & $-6.25 * * *$ & \\
\hline & $\begin{array}{l}\text { Group ADF-Statistic (between } \\
\text { dimension) }\end{array}$ & $-8.75 * * *$ & \\
\hline
\end{tabular}




\begin{tabular}{|c|c|c|c|}
\hline \multicolumn{4}{|c|}{ Cointegration:PATpc; SApc; GDPpc (intercept) } \\
\hline \multicolumn{2}{|c|}{ Null Hypothesis: no cointegration } & \multirow{2}{*}{$\begin{array}{l}\text { Statistic } \\
6.86^{* * *} \\
\end{array}$} & \multirow{2}{*}{$\begin{array}{c}\begin{array}{c}\text { Weighted } \\
\text { Statistic }\end{array} \\
0.20\end{array}$} \\
\hline \multirow{7}{*}{$\begin{array}{l}\text { Pedroni tests } \\
\text { (Engle-Granger } \\
\text { based), lag } \\
\text { length selection } \\
\text { based on SBC }\end{array}$} & Panel v-Statistic (within dimension) & & \\
\hline & Panel rho-Statistic (within dimension) & $-3.98 * * *$ & $-3.54 * * *$ \\
\hline & Panel PP-Statistic (within dimension) & $\begin{array}{c}- \\
10.70 * * *\end{array}$ & $-9.55^{* * *}$ \\
\hline & Panel ADF-Statistic (within dimension) & $11.12^{-} * * *$ & $-10.88 * * *$ \\
\hline & Group rho-Statistic (between dimension) & -0.14 & \\
\hline & Group PP-Statistic (between dimension) & $-9.50 * * *$ & \\
\hline & $\begin{array}{l}\text { Group ADF-Statistic (between } \\
\text { dimension) }\end{array}$ & $11.52 * * *$ & \\
\hline Kao test & ADF-Statistic & \multicolumn{2}{|c|}{$-4.63 * * *$} \\
\hline \multicolumn{4}{|c|}{ Cointegration: PATpc; SApc; GDPpc (intercept \& trend) } \\
\hline \multicolumn{2}{|c|}{ Null Hypothesis: no cointegration } & Statistic & $\begin{array}{c}\text { Weighted } \\
\text { Statistic }\end{array}$ \\
\hline \multirow{7}{*}{$\begin{array}{l}\text { Pedroni tests } \\
\text { (Engle-Granger } \\
\text { based), lag } \\
\text { length selection } \\
\text { based on SBC }\end{array}$} & Panel v-Statistic (within dimension) & 1.11 & -4.70 \\
\hline & Panel rho-Statistic (within dimension) & 0.74 & 0.06 \\
\hline & Panel PP-Statistic (within dimension) & $-7.91 * * *$ & $-9.42 * * *$ \\
\hline & Panel ADF-Statistic (within dimension) & $\stackrel{-}{-}$ & $-11.58 * * *$ \\
\hline & Group rho-Statistic (between dimension) & 3.26 & \\
\hline & Group PP-Statistic (between dimension) & ${ }^{-}-6^{* * *}$ & \\
\hline & $\begin{array}{l}\text { Group ADF-Statistic (between } \\
\text { dimension) }\end{array}$ & $\begin{array}{c}- \\
12.41 * * *\end{array}$ & \\
\hline
\end{tabular}

Notes: $* / * * / * * *$ means significance at the $10 \% / 5 \% / 1 \%$ levels.

Analogous tests have been applied for all four variables together (high tech exports, scientific articles per capita, patents per capita and GDP per capita), which can be seen in Tab. 6. As with the other cases, we can once again conclude that the majority of the tests reject the null hypothesis. Thus it is likely that the tested group of variables are cointegrated, which basically means that we are capable of performing cointegrated regressions on these variables to examine potential long-run causalities. 
Table 6 - The Results of Cointegration Tests for All Variables Used in Regressions

\begin{tabular}{|c|c|c|c|}
\hline \multicolumn{4}{|c|}{ Cointegration: HTEshare; SApc; PATpc; GDPpc (intercept) } \\
\hline \multicolumn{2}{|c|}{ Null Hypothesis: no cointegration } & \multirow{2}{*}{$\begin{array}{c}\text { Statistic } \\
1.52 *\end{array}$} & \multirow{2}{*}{$\begin{array}{c}\begin{array}{c}\text { Weighted } \\
\text { Statistic }\end{array} \\
1.83^{* *}\end{array}$} \\
\hline \multirow{7}{*}{$\begin{array}{l}\text { Pedroni test } \\
\text { (Engle-Granger based) } \\
\text { tests - individual } \\
\text { intercept, automatic lag } \\
\text { length selection based } \\
\text { on SIC }\end{array}$} & Panel v-Statistic (within dimension) & & \\
\hline & Panel rho-Statistic (within dimension) & 1.72 & 0.67 \\
\hline & Panel PP-Statistic (within dimension) & $-1.40^{*}$ & $-4.30 * * *$ \\
\hline & Panel ADF-Statistic (within dimension) & $-4.75 * * *$ & $-6.73 * * *$ \\
\hline & Group rho-Statistic (between dimension) & 3.72 & \\
\hline & Group PP-Statistic (between dimension) & $-3.99 * * *$ & \\
\hline & Group ADF-Statistic (between dim.) & $-8.77 * * *$ & \\
\hline Kao cointegration test & ADF-Statistic & \multicolumn{2}{|c|}{$-5.169 * * *$} \\
\hline \multicolumn{4}{|c|}{ Cointegration:HTEshare; SApc; PATpc; GDPpc (intercept \& linear trend) } \\
\hline \multicolumn{2}{|c|}{ Null Hypothesis: no cointegration } & Statistic & $\begin{array}{l}\text { Weighted } \\
\text { Statistic }\end{array}$ \\
\hline \multirow{7}{*}{$\begin{array}{l}\text { Pedroni tests } \\
\text { (Engle-Granger based) } \\
\text { tests - individual } \\
\text { intercept \& trend, } \\
\text { automatic lag length } \\
\text { selection based on SIC }\end{array}$} & Panel v-Statistic (within dimension) & $1.71 * *$ & -0.06 \\
\hline & Panel rho-Statistic (within dimension) & 1.83 & 2.32 \\
\hline & Panel PP-Statistic (within dimension) & $-7.46 * * *$ & $-6.46 * * *$ \\
\hline & Panel ADF-Statistic (within dimension) & $-9.90 * * *$ & $-8.26 * * *$ \\
\hline & Group rho-Statistic (between dimension) & 4.56 & \\
\hline & Group PP-Statistic (between dimension) & $-6.25 * * *$ & \\
\hline & Group ADF-Statistic (between dim.) & $-8.75 * * *$ & \\
\hline
\end{tabular}

Notes: $* / * * / * * *$ means significance at the $10 \% / 5 \% / 1 \%$ levels.

In accordance with our main aim we tested the long-run causalities using the FMOLS and DOLS regression described in the methodology. The FMOLS models have been slightly preferred in our analysis, due to several more suitable characteristics, such as the alternative of using heterogeneous first stage long-run coefficients.

First of all, we analyse the long-run effect of academic publications on patents, which could be also seen as an initial step towards the actual technological development of the economy. We assume that more intensive research at universities and other research institutions leads to a higher number academic publications, which could subsequently have a positive effect on patenting. This theoretical assumption was strongly supported by the empirical results from the cointegrated regressions as can be seen in Tab. 7. We applied different types of cointegration models. The models with an individual constant only, as well as 
with a constant and linear trend have been used. The leads and lags in the DOLS models have been fixed or chosen according to the Schwarz criterion. The longrun effect of academic publications on patenting is positive and statistically significant at the 5\% level of significance in nine models. The results are very similar for both the FOMLS and DOLS models. GDP per capita was used as a control variable in all models.

Table 7 - Cointegrated Regression Models with Number of Patents Per Capita as Dependent Variable

\begin{tabular}{|c|c|c|c|c|c|c|}
\hline \multicolumn{7}{|c|}{ Dependent variable: $\log (P A T p c) ;$ Pooled estimator (within dimension) } \\
\hline & (1) $\mathrm{A}$ & (2) $\mathrm{B}$ & (3) $\mathrm{C}$ & (4) D & (5) $\mathbf{E}$ & (6) $\mathrm{F}$ \\
\hline $\log (\mathrm{SApc})$ & $\begin{array}{c}0.75^{* * * *} \\
(9.73)\end{array}$ & $\begin{array}{c}0.75 * * * \\
(9.73)\end{array}$ & $\begin{array}{c}0.63 * * * \\
(6.23)\end{array}$ & $\begin{array}{c}0.76 * * * \\
(10.86)\end{array}$ & $\begin{array}{c}0.66 * * * \\
(17.95)\end{array}$ & $\begin{array}{c}0.62 * * * \\
(6.23)\end{array}$ \\
\hline $\log (\mathrm{GDPpc})$ & $\begin{array}{c}0.05 \\
(0.72)\end{array}$ & $\begin{array}{c}0.05 \\
(0.92)\end{array}$ & $\begin{array}{c}0.04 \\
(0.54)\end{array}$ & $\begin{array}{c}0.05 \\
(0.81)\end{array}$ & $\begin{array}{c}0.11^{* * *} \\
(3.15)\end{array}$ & $\begin{array}{c}0.04 \\
(0.54)\end{array}$ \\
\hline $\mathrm{R} 2$ & 0.97 & 0.97 & 0.98 & 0.97 & 0.97 & 0.98 \\
\hline Adj. R2 & 0.97 & 0.97 & 0.98 & 0.97 & 0.97 & 0.98 \\
\hline $\begin{array}{l}\text { Long-run } \\
\text { variance }\end{array}$ & 0.27 & 0.27 & 0.16 & 0.27 & 0.07 & 0.16 \\
\hline Observations & 1,075 & 1,075 & 1,024 & 1,075 & 1,075 & 1,024 \\
\hline \multicolumn{7}{|c|}{ Dependent variable: $\log (P A T p c) ;$ Group-mean estimator (between dimension) } \\
\hline & (7) $\mathbf{G}$ & (8) $\mathbf{H}$ & (9) I & (10) $\mathrm{J}$ & (11) $\mathrm{K}$ & (12) $\mathrm{L}$ \\
\hline $\log (\mathrm{SApc})$ & $\begin{array}{c}0.18^{* *} \\
(2.00)\end{array}$ & $\begin{array}{c}0.32 * * \\
(2.55)\end{array}$ & $\begin{array}{l}0.30 * \\
(1.67)\end{array}$ & $\begin{array}{l}0.16^{*} \\
(1.89)\end{array}$ & $\begin{array}{c}0.31^{* * * * *} \\
(2.55)\end{array}$ & $\begin{array}{c}0.14 \\
(0.54)\end{array}$ \\
\hline $\log (\mathrm{GDPpc})$ & $\begin{array}{c}0.31 * * * \\
(3.13)\end{array}$ & $\begin{array}{c}0.35 * * * \\
(2.80)\end{array}$ & $\begin{array}{c}0.53 \\
(3.30)\end{array}$ & $\begin{array}{c}0.35 * * * \\
(3.89)\end{array}$ & $\begin{array}{c}0.35 * * * \\
(2.79)\end{array}$ & $\begin{array}{c}0.73 \\
(1.54)\end{array}$ \\
\hline $\begin{array}{l}\text { Long-run } \\
\text { variance }\end{array}$ & 0.05 & 0.04 & 0.03 & 0.04 & 0.04 & 0.02 \\
\hline Observations & 1,075 & 1,024 & 952 & 1,019 & 1,024 & 952 \\
\hline
\end{tabular}

Notes: $* / * * * * *$ means significance at the 10\%/ 5\%/ 1\% levels; (.) denotes t-statistics; long-run variances calculated based on Bartlett kernel and Newey-West bandwidth have been used for coefficient covariances; A - FMOLS (pooled estimator), constant included, coefficient covariance matrix with homogenous variances; B - FMOLS (pooled estimator), constant included, coefficient covariance matrix with heterogeneous variances; C - DOLS (pooled estimator), constant included, lags and leads based on the SIC; homogenous variances; D - FMOLS (pooled estimator), constant \& linear trend, coefficient covariance matrix with homogenous variances; E - FMOLS (pooled estimator), constant \& linear trend, coefficient covariance matrix with heterogeneous variances; first-stage residuals use heterogeneous longrun coefficients; F- DOLS (pooled estimator), constant, lags and leads based on the SIC; heterogenous variances; G - FMOLS (group-mean estimator), constant included; H - DOLS (group-mean estimator), constant included, lags and leads included based on the SIC; I - DOLS (group-mean estimator), constant included, 1 lead and 1 lag (fixed leads and lags specification); J - FMOLS (group-mean estimator), constant \& linear trend included; K - DOLS (group-mean estimator), linear trend, lags and leads included based on the SIC; L - DOLS (group-mean estimator), linear trend, 1 lead and 1 lag (fixed leads and lags). 
In the next models we focused our analysis on the long-run causalities between scientific articles and high technology exports. In this case we again found rather strong empirical support for our assumption that scientific articles as an indicator of academic activities intensity have a positive effect on the high technology exports in the long run. In order to check for the robustness of our results we apply different estimation approaches with different assumptions. The assumed positive effect is statistically significant at the 5\% level in most of the cointegrated regression models, which can be seen in Tab. 8. In particular, this effect is significant in all models which are based on a group mean estimator.

It is important to note that we have not controlled for the potential effect of patenting in the previous regressions. Despite academic publications seeming to have a positive effect on patenting, patenting itself could also be another important factor affecting the share of high technology exports. This effect has been taken into account in the next set of regression models which include high technology exports as the dependent variable and scientific articles per capita, GDP per capita and patents per capita as independent variables. A wide variety of long-run causal estimators has been used in this case in order to check the robustness of the results. The results from the pooled estimators are summarized in Tab. 9. According to these, the effect of scientific articles is statistically significant at least at the $10 \%$ level in all FMOLS models (upper part of Tab. 9). On the other hand we get somewhat mixed results for the DOLS estimator. Half of the DOLS models support our assumption about the positive effect of scientific articles on high technology exports at least at the 5\% level of significance. In addition the effect of patents appears to be insignificant in most of the DOLS and FMOLS models when controlling for academic publications and GDP per capita.

Table 8 - FMOLS and DOLS Regressions with Share of High Technology Exports as Dependent Variable

\begin{tabular}{|c|c|c|c|c|c|c|}
\hline \multicolumn{7}{|c|}{ Dependent variable: HTEshare; Pooled estimator (within dimension) } \\
\hline & (1) $\mathrm{A}$ & (2) $\mathbf{B}$ & (3) $\mathrm{C}$ & (4) D & (5) $\mathbf{E}$ & (6) $\mathrm{F}$ \\
\hline $\log (\mathrm{SApc})$ & $\begin{array}{l}1.70^{*} \\
(1.94)\end{array}$ & $\begin{array}{c}1.70 * * * \\
(2.43)\end{array}$ & $\begin{array}{l}2.07 * * \\
(2.10)\end{array}$ & $\begin{array}{c}1.73 \\
(1.09)\end{array}$ & $\begin{array}{l}1.40^{*} \\
(1.65)\end{array}$ & $\begin{array}{l}4.47 * \\
(1.91)\end{array}$ \\
\hline $\log (\mathrm{GDPpc})$ & $\begin{array}{c}0.18 \\
(0.20)\end{array}$ & $\begin{array}{c}0.18 \\
(0.18 .)\end{array}$ & $\begin{array}{c}0.88 \\
(0.96)\end{array}$ & $\begin{array}{l}-1.88 \\
(-0.63)\end{array}$ & $\begin{array}{c}-2.77 \\
(-1.55)\end{array}$ & $\begin{array}{l}-6.53 * \\
(-1.78)\end{array}$ \\
\hline $\mathrm{R} 2$ & 0.91 & 0.91 & 0.95 & 0.94 & 0.94 & 0.96 \\
\hline Adj. R2 & 0.91 & 0.91 & 0.93 & 0.94 & 0.93 & 0.94 \\
\hline $\begin{array}{l}\text { Long-run } \\
\text { variance }\end{array}$ & 35.23 & 35.23 & 18.51 & 23.39 & 11.03 & 11.89 \\
\hline Observations & 1,072 & 1,072 & 993 & 1,072 & 1,072 & 1,001 \\
\hline
\end{tabular}




\begin{tabular}{|l|c|c|c|c|c|c|}
\hline \multicolumn{7}{|c|}{ Dependent variable: HTEshare; Group mean estimator (between dimension) } \\
\hline & $\mathbf{( 7 ) ~ G}$ & $\mathbf{( 8 ) ~ H}$ & $\mathbf{( 9 )} \mathbf{I}$ & $\mathbf{( 1 0 )} \mathbf{J}$ & $\mathbf{( 1 1 ) ~ K}$ & $\mathbf{( 1 2 )} \mathbf{~}$ \\
\hline $\log (\mathrm{SApc})$ & $\begin{array}{c}6.24 * * * \\
(3.34)\end{array}$ & $\begin{array}{c}7.68 * * \\
(2.21)\end{array}$ & $\begin{array}{c}6.00 * * * \\
(2.90)\end{array}$ & $\begin{array}{c}5.82^{* * *} \\
(3.26)\end{array}$ & $\begin{array}{c}16.47 * * * \\
(3.03)\end{array}$ & $\begin{array}{c}14.15^{* *} \\
(2.53)\end{array}$ \\
\hline $\log (\mathrm{GDPpc})$ & $\begin{array}{c}-3.53 * * * \\
(-3.03)\end{array}$ & $\begin{array}{c}-6.65 * * * \\
(-3.10)\end{array}$ & $\begin{array}{c}-5.44 * * * \\
(-4.21)\end{array}$ & $\begin{array}{c}-10.84 * * * \\
(-4.15)\end{array}$ & $\begin{array}{c}-20.02 * * * \\
(-3.06)\end{array}$ & $\begin{array}{c}-19.54 * * * \\
(-2.57)\end{array}$ \\
\hline $\begin{array}{l}\text { Long-run } \\
\text { variance }\end{array}$ & 14.99 & 9.07 & 15.79 & 9.23 & 8.55 & 8.91 \\
\hline Observations & 1,072 & 993 & 1,020 & 1,016 & 1,001 & 1,016 \\
\hline
\end{tabular}

Notes: $* / * * / * * *$ means significance at the 10\%/ 5\%/ 1\% levels; (.) denotes t-statistics; long-run variances calculated based on Bartlett kernel and Newey-West bandwidth have been used for coefficient covariances; A - FMOLS (pooled estimator), constant included, coefficient covariance matrix with homogenous variances; B - FMOLS (pooled estimator), constant included, coefficient covariance matrix with heterogeneous variances; C - DOLS (pooled estimator), constant included, lags and leads included based on the AIC; D - FMOLS (pooled estimator), linear trend, coefficient covariance matrix with homogenous variances; E - FMOLS (pooled estimator), constant \& linear trend, coefficient covariance matrix with heterogeneous variances, first-stage residuals use heterogeneous long-run coefficients; FDOLS (pooled estimator), linear trend; lags and leads based on the AIC; coefficient covariance matrix with heterogeneous variances; G - FMOLS (group-mean estimator), constant included; H - DOLS (groupmean estimator), constant included, lags and leads included based on the AIC; I - DOLS (group-mean estimator), constant included, lags and leads included based on the SIC, individual HAC (Newey-West) standard errors \& covariances; J - FMOLS (group-mean estimator), constant \& linear trend included; K DOLS (group-mean estimator), linear trend, lags and leads included based on the AIC; L - DOLS (groupmean estimator), linear trend, lags and leads included based on the SIC; individual; HAC (Newey-West) standard errors \& covariances.

Table 9 - The Results of Models with Pooled Estimator - Within Dimension

\begin{tabular}{|l|c|c|c|c|c|c|}
\hline \multicolumn{7}{|c|}{ Dependent variable: HTEshare; FMOLS: (dependent variable: HTEshare) } \\
\hline & $\mathbf{( 1 )} \mathbf{A}$ & $\mathbf{( 2 )} \mathbf{B}$ & $\mathbf{( 3 )} \mathbf{C}$ & $\mathbf{( 4 )} \mathbf{D}$ & $\mathbf{( 5 )} \mathbf{E}$ & $\mathbf{( 6 )} \mathbf{~}$ \\
\hline $\log (\mathrm{SApc})$ & $\begin{array}{c}1.26^{* *} \\
(2.33)\end{array}$ & $\begin{array}{c}1.26^{* * *} \\
(3.09)\end{array}$ & $\begin{array}{c}1.27^{*} \\
(1.92)\end{array}$ & $\begin{array}{c}1.46^{*} \\
(1.70)\end{array}$ & $\begin{array}{c}1.46^{* *} \\
(2.29)\end{array}$ & $\begin{array}{c}1.33^{* * *} \\
(83.01)\end{array}$ \\
\hline $\log (\mathrm{PATpc})$ & $\begin{array}{c}0.41 \\
(1.37)\end{array}$ & $\begin{array}{c}0.41^{*} \\
(1.76)\end{array}$ & $\begin{array}{c}0.55 \\
(1.44)\end{array}$ & $\begin{array}{c}-0.38 \\
(-1.05)\end{array}$ & $\begin{array}{c}-0.38 \\
(-1.23)\end{array}$ & $\begin{array}{c}3.56^{* * *} \\
(11.85)\end{array}$ \\
\hline $\log (\mathrm{GDPpc})$ & $\begin{array}{c}0.26 \\
(0.53)\end{array}$ & $\begin{array}{c}0.26 \\
(0.63)\end{array}$ & $\begin{array}{c}0.15 \\
(0.24)\end{array}$ & $\begin{array}{c}-1.89 \\
(-1.19)\end{array}$ & $\begin{array}{c}-1.89 \\
(-1.50)\end{array}$ & $\begin{array}{c}-6.61 * * * \\
(-264.5)\end{array}$ \\
\hline R2 & 0.91 & 0.91 & 0.91 & 0.94 & 0.94 & 0.93 \\
\hline Adj. R2 & 0.91 & 0.91 & 0.91 & 0.93 & 0.93 & 0.92 \\
\hline Long-run variance & 11.15 & 11.15 & 10.83 & 6.52 & 6.52 & 5.09 \\
\hline Observations & 1,059 & 1,059 & 1,059 & 1,059 & 1,059 & 1,059 \\
\hline
\end{tabular}




\begin{tabular}{|l|c|c|c|c|c|c|}
\hline \multicolumn{7}{|c|}{ Dependent variable: HTEshare; DOLS: (dependent variable: HTEshare) } \\
\hline & $\mathbf{( 7 )} \mathbf{~}$ & $\mathbf{( 8 )} \mathbf{H}$ & $\mathbf{( 9 )} \mathbf{I}$ & $\mathbf{( 1 0 )} \mathbf{J}$ & $\mathbf{( 1 1 )} \mathbf{~ K}$ & $\mathbf{( 1 2 )} \mathbf{~ L}$ \\
\hline $\log (\mathrm{SApc})$ & $\begin{array}{c}2.72^{* *} \\
(2.05)\end{array}$ & $\begin{array}{c}1.34 \\
(1.36)\end{array}$ & $\begin{array}{c}0.068^{* * *} \\
(3.32)\end{array}$ & $\begin{array}{c}2.32 \\
(1.35)\end{array}$ & $\begin{array}{c}2.32 \\
(1.49)\end{array}$ & $\begin{array}{c}1.10^{* * *} \\
(3.42)\end{array}$ \\
\hline $\log (\mathrm{PATpc})$ & $\begin{array}{c}0.07 \\
(0.06)\end{array}$ & $\begin{array}{c}0.04 \\
(0.06)\end{array}$ & $\begin{array}{c}0.32^{* *} \\
(2.13)\end{array}$ & $\begin{array}{c}-0.70 \\
(-0.85)\end{array}$ & $\begin{array}{c}-0.70 \\
(-0.79)\end{array}$ & $\begin{array}{c}-0.28 \\
(-1.56)\end{array}$ \\
\hline $\log (\mathrm{GDPpc})$ & 0.46 & 0.22 & $0.56^{* *}$ & $-5.78^{*}$ & $-5.78^{* *}$ & $-2.05^{* *}$ \\
& $(0.43)$ & $(0.24)$ & $(2.38)$ & $(-1.90)$ & $(-2.07)$ & $(-2.33)$ \\
\hline $\mathrm{R}^{2}$ & 0.97 & 0.96 & 0.96 & 0.95 & 0.95 & 0.95 \\
\hline Adj. $\mathrm{R}^{2}$ & 0.93 & 0.93 & 0.93 & 0.94 & 0.94 & 0.94 \\
\hline Long-run variance & 10.13 & 14.58 & 14.58 & 16.62 & 16.62 & 16.62 \\
\hline Observations & 935 & 985 & 985 & 1,057 & 1,057 & 1,057 \\
\hline
\end{tabular}

Notes: $* / * * * * *$ means significance at the 10\%/ 5\%/ 1\% levels; (.) denotes t-statistics; long-run variances calculated based on Bartlett kernel and Newey-West bandwidth have been used for coefficient covariances; A - FMOLS pooled estimator; constant included, coefficient covariance matrix with homogenous variances, first-stage residuals use heterogeneous long-run coefficients; B - FMOLS pooled estimator; constant included, coefficient covariance matrix with heterogeneous variances, first-stage residuals use heterogeneous long-run coefficients; C - FMOLS pooled estimator; constant included, coefficient covariance matrix with heterogeneous variances; D - FMOLS pooled estimator; linear trend included, coeff. cov. matrix with homogenous variances; E - FMOLS pooled estimator; constant \& linear trend included, coeff. cov. matrix with heterogeneous variances; F - FMOLS pooled weighted estimator; constant\& linear trend included; coefficient covariance matrix with homogenous variances, first-stage residuals use heterogeneous long-run coefficients; G - DOLS pooled estimator; constant included, fixed leads and lags (leads=1, lags=1), coefficient covariance matrix with heterogeneous variances; $\mathrm{H}$ - DOLS pooled estimator; constant included, leads and lags based on SIC, long-run variance, coefficient covariance matrix with homogenous variances; I - DOLS pooled weighted estimator; constant included, leads and lags based on SIC, long-run variance, coefficient covariance matrix with homogenous variances; J - DOLS pooled estimator; constant \& linear trend included, leads and lags based on SIC, coefficient covariance matrix with homogenous variances; K - DOLS pooled estimator; linear trend included, leads and lags based on SIC, coefficient covariance matrix with heterogeneous variances; L DOLS pooled weighted estimator; linear trend included, leads and lags based on SIC, coefficient covariance matrix with heterogeneous variances.

The results from the grouped-mean estimators are summarized in Tab. 10. As can be seen, the results achieved by DOLS and FMOLS group-mean estimators are mostly similar. Scientific articles have a positive and statistically significant effect on high technology exports in all regressions. As stated before, scientific articles have a significant effect on both patents and high technology exports. The effect of patents is, however, positive and significant only when excluding the scientific articles variable from the models. Our results thus strongly suggest that the outputs of basic science could be seen as an actual source of technological development of the economy. This effect seems to be even more significant and intensive when using the group-mean estimator considering the "between dimension" of panel data. 
Table 10 - The Results of Models with Group-Mean Estimator (between Dimension)

\begin{tabular}{|c|c|c|c|c|c|}
\hline \multicolumn{6}{|c|}{ FMOLS: (dependent variable: HTEshare) } \\
\hline & (1) $\mathrm{A}$ & (2) $\mathrm{B}$ & (3) $\mathrm{C}$ & (4) $\mathrm{D}$ & (5) $\mathrm{E}$ \\
\hline $\log (\mathrm{SApc})$ & $\begin{array}{c}2.93 * * \\
(1.90)\end{array}$ & & $\begin{array}{c}3.78 * * * \\
(3.06)\end{array}$ & $\begin{array}{c}5.94 * * * \\
(3.37)\end{array}$ & \\
\hline $\log (\mathrm{PATpc})$ & $\begin{array}{c}0.47 \\
(0.68)\end{array}$ & $\begin{array}{c}2.66 * * * \\
(2.73)\end{array}$ & $\begin{array}{c}0.92 \\
(1.37)\end{array}$ & & $\begin{array}{l}1.68 * * \\
(2.01)\end{array}$ \\
\hline $\log (\mathrm{GDPpc})$ & $\begin{array}{c}-1.20 \\
(-1.09)\end{array}$ & $\begin{array}{c}0.19 \\
(0.21)\end{array}$ & $\begin{array}{c}-5.91 * * * \\
(-2.60)\end{array}$ & $\begin{array}{c}-10.46^{* * * *} \\
(-4.20)\end{array}$ & $\begin{array}{c}-3.18 \\
(-1.28)\end{array}$ \\
\hline Long-run variance & 9.17 & 15.18 & 5.04 & 8.88 & 8.48 \\
\hline Observations & 1,059 & 1,124 & 1,059 & 1,072 & 1,124 \\
\hline \multicolumn{6}{|c|}{ DOLS: (dependent variable: HTEshare) } \\
\hline & (6) $\mathrm{F}$ & (7) $\mathrm{G}$ & (8) $\mathrm{H}$ & (9) I & (10) $\mathrm{J}$ \\
\hline $\log (\mathrm{SApc})$ & $\begin{array}{c}12.95^{* *} \\
(2.30) \\
\end{array}$ & $\begin{array}{c}14.54 * * * \\
(3.63) \\
\end{array}$ & $\begin{array}{c}24.73 * * * \\
(3.27) \\
\end{array}$ & $\begin{array}{c}4.39 * * \\
(1.99) \\
\end{array}$ & \\
\hline $\log (\mathrm{PATpc})$ & $\begin{array}{c}-5.10 * * \\
(-2.45) \\
\end{array}$ & $\begin{array}{c}-4.58 * * * \\
(-3.26) \\
\end{array}$ & $\begin{array}{c}-1.19 \\
(-0.38) \\
\end{array}$ & $\begin{array}{c}-0.20 \\
(-0.16) \\
\end{array}$ & $\begin{array}{c}2.38 \\
(1.44) \\
\end{array}$ \\
\hline $\log (\mathrm{GDPpc})$ & $\begin{array}{c}-2.41 \\
(-0.88)\end{array}$ & $\begin{array}{c}-1.60 \\
(-0.73)\end{array}$ & $\begin{array}{l}14.31 \\
(1.23)\end{array}$ & $\begin{array}{c}-7.39 * * \\
(-2.08)\end{array}$ & $\begin{array}{c}-3.76 \\
(-1.06)\end{array}$ \\
\hline Long-run variance & 3.04 & 5.48 & 2.29 & 8.46 & 8.91 \\
\hline Observations & 935 & 985 & 935 & 1,057 & 1,060 \\
\hline
\end{tabular}

Notes: $* / * * / * * *$ means significance at the 10\%/ 5\%/ 1\% levels; (.) denotes t-statistics; long-run variances calculated based on Bartlett kernel and Newey-West bandwidth have been used for coefficient covariances; coefficient covariance matrix with homogenous variances; A - FMOLS group-mean estimator; constant included; B - FMOLS group-mean estimator; constant included; C - FMOLS groupmean estimator; constant \& linear trend included; D - FMOLS group-mean estimator; constant \& linear trend included; E - FMOLS group-mean estimator; constant \& linear trend included; F - DOLS groupmean estimator; constant included; fixed leads and lags (leads=1, lags=1); G - DOLS group-mean estimator; constant included; leads and lags based on SIC; H - DOLS group-mean estimator; constant \& linear trend included; fixed leads and lags $(1,1)$; I - DOLS group-mean estimator; constant \& linear trend included; leads and lags based on SIC; individual HAC, (Newey-West) covariance matrix estimator; J DOLS group-mean estimator, constant \& linear trend included; leads and lags based on SIC.

In the next and final step of our analysis, we use the panel vector error correction model (VECM) to capture potential short-run causalities. The results of the analysis can be seen in the Tab. 11. Using this kind of model we can also revaluate the significance of the long-run relationship using the error correction term and also calculate the speed of the expected return to long-run equilibrium. The number of lags included in the models was selected using the Schwarz criterion. This resulted in two lags for both models. 
Table 11 - The Results of the VECM Models

\begin{tabular}{|c|c|c|c|c|}
\hline \multirow{2}{*}{\begin{tabular}{|l} 
Coef. \\
$\mathrm{C}(1)$
\end{tabular}} & \multicolumn{4}{|c|}{ Dependent variable: $\triangle H T E$ share } \\
\hline & $\Delta$ HTEshare $(-1)$ & $\begin{array}{l}-0.02 \\
(1.22)\end{array}$ & $\Delta$ HTEshare $(-1)$ & $\begin{array}{c}0.02 \\
(0.76)\end{array}$ \\
\hline $\mathrm{C}(2)$ & $\Delta$ HTEshare(-2) & $\begin{array}{c}0.02 \\
(0.75)\end{array}$ & $\Delta$ HTEshare(-2) & $\begin{array}{c}0.02 \\
(0.78)\end{array}$ \\
\hline $\mathrm{C}(3)$ & $\Delta \log (\operatorname{SApc}(-1))$ & $\begin{array}{c}0.93 \\
(1.02)\end{array}$ & $\Delta(\log (\operatorname{SApc}(-1)))$ & $\begin{array}{c}0.91 \\
(1.05)\end{array}$ \\
\hline $\mathrm{C}(4)$ & $\Delta \log (\operatorname{SApc}(-2))$ & $\begin{array}{c}0.92 \\
(1.05)\end{array}$ & $\Delta(\log (\operatorname{SApc}(-2)))$ & $\begin{array}{c}0.89 \\
(1.05)\end{array}$ \\
\hline $\mathrm{C}(5)$ & $\Delta \log (\operatorname{PATpc}(-1))$ & $\begin{array}{l}-0.04 \\
(-1.62)\end{array}$ & $\Delta(\log (\operatorname{GDPpc}(-1)))$ & $\begin{array}{l}-3.94 * \\
(-1.86)\end{array}$ \\
\hline $\mathrm{C}(6)$ & $\Delta \log (\operatorname{PATpc}(-2))$ & $\begin{array}{c}0.02 \\
(0.64)\end{array}$ & $\Delta(\log (\operatorname{GDPpc}(-1)))$ & $\begin{array}{c}1.92 \\
(0.94)\end{array}$ \\
\hline $\mathrm{C}(7)$ & $\Delta(\log (\operatorname{GDPpc}(-1)))$ & $\begin{array}{l}-3.84 * \\
(-1.77)\end{array}$ & & \\
\hline $\mathrm{C}(8)$ & $\Delta(\log (\operatorname{GDPpc}(-2)))$ & $\begin{array}{l}1.65 \\
(0.79)\end{array}$ & & \\
\hline \multirow[t]{6}{*}{$\mathrm{C}(9)$} & ECT(-1) & $\begin{array}{c}-0.015 * * * \\
(-4.2)\end{array}$ & ECT(-1) & $\begin{array}{c}-0.01 * * * \\
(-4.04)\end{array}$ \\
\hline & Constant & $\begin{array}{c}0.09 \\
(0.63)\end{array}$ & Constant & $\begin{array}{c}0.08 \\
(0.56)\end{array}$ \\
\hline & $\begin{array}{l}\text { Wald test: } \\
C(3)=C(4)=0\end{array}$ & 1.98 & $\begin{array}{l}\text { Wald test: } \\
\mathrm{C}(3)=\mathrm{C}(4)=0\end{array}$ & 2.04 \\
\hline & $\begin{array}{l}\text { Wald test: } \\
C(5)=C(6)=0\end{array}$ & 2.64 & $\begin{array}{l}\text { Wald test: } \\
C(5)=C(6)=0\end{array}$ & 3.64 \\
\hline & $\mathrm{R}^{2}$ & 0.03 & $\mathrm{R}^{2}$ & 0.02 \\
\hline & $\begin{array}{l}\text { Number of } \\
\text { observations }\end{array}$ & 988 & $\begin{array}{l}\text { Number of } \\
\text { observations }\end{array}$ & 1,001 \\
\hline
\end{tabular}

Notes: $* / * * / * * *$ means significance at the $10 \% / 5 \% / 1 \%$ levels. $(-1) /(-2)$ means the variable is lagged by one/two years.

Based on the results of Wald test, both variables capturing scientific articles and patenting are not significant. Regression coefficients by both lagged variables are jointly not statistically significant. Hence, we can say that there is no evident short-run effect of the independent variables on the dependent variable. Most of the variables are insignificant and the coefficient of determination is very low. However, the coefficients of the error correction term are significantly negative, which is fully in line with the assumptions of a long-run stable relationship between variables. The speed of adjustment to the long run equilibrium between each pair of variables is slow but identical in both models. 


\section{CONCLUSION}

The outputs of basic and applied research could have a positive effect on the development of new technologies with further impacts on the economy, particularly in the long run. Several studies confirm that research at universities is an essential part of the innovation process within a country (such as for example Jaffe, 1989). This is true in the linear model of innovation as well as in the triple helix model. Similarly, Herrera, Muñoz-Doyague and Nieto (2010) argue that scientific knowledge provided by public researchers supports both inputs and outputs of the firms' innovation process. However, there is only very little empirical research done on estimating any long-run effects, particularly in a multi-country context.

Our analysis has focused on supplementing our understanding in this area, by primarily focusing on testing the long-run as well as short-run effects arising from academic publications and patents on the share of high technology exports. The results mostly suggest that there are virtually no or only very little short-run effects between these three variables. Despite this, it seems likely that there could be some sort of causality in the Granger sense between scientific articles and high-technology exports. However, the results suggest that there are several significant long-run causalities between the selected variables. The number of patents in the country is positively affected by scientific articles in the long run. This could be interpreted as the demonstration of the long-run relationship between basic research and applied research or innovation. Even more interesting is the potential effect of scientific articles on the technological development of the economy. Taking into account more recent views on innovation rather than the pure linear innovation process, we test not only the effect of scientific articles on patenting but also on high-technology exports. Our results strongly suggest that there is a long-run positive effect of academic scientific activities on technological development. This evidence is somewhat stronger when using group-mean DOLS and FMOLS estimators. These results are in some respect supplement the findings of Nguyen and Pham (2011) and McMillan, Mauri and Casey (2014). Based on our results it seems likely that the positive effect of scientific articles on technological development is robust even when controlling for the number of patents. On the other hand, the similar effect of patenting is considerably less significant and less intensive, especially when controlling for scientific articles.

Thus our results indicate the importance of university research. In this they are consistent with both the NIS and the RIS approach and thus support a policy framework based on these approaches. Furthermore, several policy implications follow from our results. Firstly, there is strong evidence that R\&D intensity at universities and other research organisations is a fundamental factor supporting the technological development of the economy in the long-run. Hence, support of basic science even in the less applied form seems to be a good way to enhance the development of new technologies and increase the share of exports with higher added value in the long-run. Secondly despite recent undergoing debates, 
the number of good-quality papers appears to capture the impact of basic research on $R \& D$ technological impact in the long-run. The positive effect of basic research could in part be distributed into the economy through the patenting path. However, according to our results, it seems likely that there are other ways (such as positive spillovers) as to how basic research facilitates the technological development of an economy. Knowledge from basic research can be transferred to private sector firms through informal contacts, networks and consultancies. In addition it is reasonable to assume that good quality research publications reflect the quality of the academics. In this case their significance may reflect the transfer of knowledge, often tacit knowledge, though face to face interactions (Asheim and Gertler, 2005) and consultancies. It may also reflect the quality of $\mathrm{PhD}$ training and the impact that has on private sector performance (Mowery and Sampat, 2004). In this case it is right for RIS and NIS to encourage basic research, as with much public sector research funding in the countries of the EU, and formal attempts to evaluate and reward research as in the REF in the UK.

It is important to note that despite our considerable effort to achieve the most relevant results, our analysis has certain limitations. First, the variables used in the analysis are only proxies for the intensity of science and technological development of the economy. Secondly, we assumed that the effect of R\&D intensity is largely localised in the same country. Hence, we do not take into account potential direct effects and spillovers crossing borders. Moreover, the scope of the data has been significantly limited by the data availability. This also limited the number of control variables. Despite the fact that the problem of endogenity has been to a large extent solved by using panel DOLS and FMOLS estimators, more control variables might improve the robustness of our results even more in this respect. Our approach does not allow us to capture differences between countries. Moreover, we are also not able to distinguish between the different research areas or different knowledge producers. The effects of scientific activities in diverse research areas should be of course significantly different. Potential further research can be focused on the examination of differences between research areas and different knowledge producers. Furthermore, there is also space for further research focused on examining the knowledge transfer from academia to business in more detail. More research needs to be done to allow us greater insight into the mechanisms by which university based research impacts on the economy.

\section{ACKNOWLEDGEMENT}

We give our deepest thanks to John Hudson, professor of economics at University of Bath, for all his ideas, comments, support and motivation he provided during our professional cooperation - not just on this research. The paper was finalized and submitted after his death and John did not see the final version, but we believe he would be happy to know that we are carrying the torch and continue to work hard on the ideas he shared with us. We were 
lucky to know and to work together with such an exceptional researcher and such an exceptional personality. His untimely death robbed us of a hardworking and caring colleague, and we all miss him very much.

We would like to thank the two anonymous reviewers for their valuable suggestions and comments.

This research was supported by the Slovak Research and Development Agency (APVV), APVV-14-0512 "Universities and regional development".

\section{REFERENCES}

Anselin, L., Varga, A. and Acs, Z., 1997. Local geographic spillovers between university research and high technology innovations. Journal of urban economics, 42(3), pp.422-448. https://doi.org/10.1006/juec.1997.2032.

Artz, K.W., Norman, P.M., Hatfield, D.E. and Cardinal, L.B., 2010. A longitudinal study of the impact of R\&D, patents, and product innovation on firm performance. Journal of Product Innovation Management, 27(5), pp.725-740. https://doi.org/10.1111/j.1540-5885.2010.00747.x.

Asheim, B. and Gertler, M., 2005. The geography of innovation“. In: J. Fagerberg, D. Mowery and R. Nelson, eds. The Oxford Handbook of Innovation. Oxford: Oxford University Press. pp.291-317.

Bercovitz, J. and Feldman, M., 2006. Entrepreneurial universities and technology transfer: A conceptual framework for understanding knowledge-based economic development. The Journal of Technology Transfer, 31(1), pp.175-188. https://doi.org/10.1007/s10961-005-5029-z.

Breitung, J., 2000. The local power of some unit root tests for panel data. In: B.H. Baltagi, eds. Nonstationary Panels, Panel Cointegration, and Dynamic Panels - vol. 15. Amsterdam: Elsevier. pp.161-177.

Breschi, S., Lissoni, F. and Montobbio, F. 2005. From publishing to patenting: Do productive scientists turn into academic inventors? Revue d'économie industrielle, 110(1), pp.75-102. https://doi.org/10.3406/rei.2005.3073.

Carayol, N. and Matt, M., 2004. Does research organization influence academic production?: Laboratory level evidence from a large European university. Research Policy, 33(8), pp.1081-102. https://doi.org/10.1016/j.respol. 2004.03.004.

Castellacci, F. and Natera, J.M., 2013. The dynamics of national innovation systems: A panel cointegration analysis of the coevolution between innovative capability and absorptive capacity. Research Policy, 42(3), pp.579-594. https://doi.org/10.1016/j.respol.2012.10.006. 
Chatterton P. and Goddard, J., 2000. The response of higher education institutions to regional needs. European Journal of Education, 35(4), pp.475496.

Chesbrough, H.W., 2006. Open innovation: The new imperative for creating and profiting from technology. Boston, MA: Harvard Business Press.

Choi, I., 2001. Unit root tests for panel data. Journal of International Money and Finance, 20(2), pp.249-272. https://doi.org/10.1016/S0261-5606(00)00048-6.

Czarnitzki, D., Glänzel, W. and Hussinger, K., 2007. Patent and publication activities of German professors: An empirical assessment of their coactivity. Research Evaluation, 16(4), https://doi.org/10.3152/095820207X254439.

pp.311-319.

Czarnitzki, D., Hussinger, K. and Schneider, C., 2012. The nexus between science and industry: evidence from faculty inventions. The Journal of Technology Transfer, 37(5), pp.755-776. https://doi.org/10.1007/s10961-0119214-y.

Etzkowitz, H. and Leydesdorff, L., 2000. The dynamics of innovation: from National Systems and "Mode 2" to a Triple Helix of university-industrygovernment relations. Research Policy, 29(2), pp.109-123. https://doi.org/10.1016/S0048-7333(99)00055-4.

Freeman, C., 1987. Technology Policy and Economic Performance: Lessons from Japan. London: Pinter.

Gunasekara, C., 2006. Reframing the role of universities in the development of regional innovation systems. Journal of Technology Transfer, 31(1), pp.101-113. https://doi.org/10.1007/s10961-005-5016-4.

Herrera, L., Muñoz-Doyague, M.F. and Nieto, M., 2010. Mobility of public researchers, scientific knowledge transfer, and the firm's innovation process. Journal of Business Research, 63(5), pp.510-518. https://doi.org/10.1016/j.jbusres.2009.04.010.

Hudson, J. and Minnea, A., 2013. Innovation, intellectual property rights, and economic development: A unified empirical investigation. World Development, 46, pp.66-78. https://doi.org/10.1016/j.worlddev.2013.01.023.

Im, K.S., Pesaran, M.H. and Shin, Y., 2003. Testing for unit roots in heterogeneous panels. Journal of Econometrics, 115(1), pp. 53-74.

Jaffe, A.B., 1989. Real effects of academic research. American Economic. Review, 79(5), pp.957-970.

Kao, C. and Chiang, M.H., 2000. On the estimation and inference of cointegrated regression in panel data. Advances in. Econometrics, 15, pp.179-222. 
Kao, C., 1999. Spurious regression and residual based Tests for cointegration in panel data. Journal of Econometrics, 90(1), pp.1-44. https://doi.org/10.1016/S0304-4076(98)00023-2.

Lebeau, L.M., Laframboise, M.C., Larivière, V. and Gingras, Y., 2008. The effect of university-industry collaboration on the scientific impact of publications: the Canadian case, 1980 -2005. Research Evaluation, 17(3), pp.227-232. https://doi.org/10.3152/095820208X331685.

Levin, A., Lin, C.F. and Chu, C.S.J., 2002. Unit root tests in panel data: Asymptotic and finite sample properties. Journal of Econometrics, 108(1), pp.122.

Lundvall, B-Å., 1992. National Systems of Innovation: Towards a Theory of Innovation and Interactive Learning. London: Pinter.

Maddala, G.S. and Wu, S., 1999. A comparative study of unit root tests with panel data and a new simple test. Oxford Bulletin of Economics and statistics, 61(S1), pp.631-652. https://doi.org/10.1111/1468-0084.0610s1631.

Maglio, P.P., Srinivasan, S., Kreulen, J.T. and Spohrer, J., 2006. Service systems, service scientists, SSME, and innovation. Communications of the ACM, 49(7), pp.81-85.

McMillan, G.S., Mauri, A. and Casey, D.L., 2014. The scientific openness decision model: "Gaming" the technological and scientific outcomes. Technological Forecasting and Social Change, 86, pp.132-142. https://doi.org/10.1016/j.techfore.2013.08.021.

Minguillo, D. and Thelwall, M., 2015. Research excellence and universityindustry collaboration in UK science parks. Research Evaluation, 24(2), pp.18196. https://doi.org/10.1093/reseval/rvu032.

Montobbio, F. and Rampa, F., 2005. The impact of technology and structural change on export performance in nine developing countries. World Development, 33(4), pp.527-547. https://doi.org/10.1016/j.worlddev.2005.01.001.

Mowery, D.C. and Sampat, B.N., 2004. Universities in National Innovation Systems. In: J. Fagerberg, D.C. Mowery and R.N. Nelson, eds. The Oxford Handbook of Innovation. Oxford: Oxford University Press. pp.209-239. https://doi.org/10.1093/oxfordhb/9780199286805.001.0001.

Nelson, R.R., 1993. National Innovation Systems: a Comparative Study. New York: Oxford University Press.

Nguyen, T.V. and Pham, L.T., 2011. Scientific output and its relationship to knowledge economy: an analysis of ASEAN countries. Scientometrics, 89(1), pp.107-117. https://doi.org/10.1007/s11192-011-0446-2.

Pedroni, P., 2000. Fully modified OLS for heterogeneous cointegrated panels. Advances in Econometrics, 15, pp.93-130. https://doi.org/10.1016/S07319053(00)15004-2. 
Pedroni, P., 2001. Purchasing power parity tests in cointegrated panels. The Review of Economics and Statistics, 83, pp.727-31. https://doi.org/10.1162/003465301753237803.

Pedroni, P., 2004. Panel cointegration: asymptotic and finite sample properties of pooled time series tests with an application to the PPP hypothesis. Econometric theory, 20(3), pp.597-625. https://doi.org/10.1017/S0266466604203073.

Perkmann, M., Tartari, V., McKelvey, M., Autio, E., ... and Krabel, S., 2013. Academic engagement and commercialisation: A review of the literature on university-industry relations. Research Policy, 42(2), pp.423-442. https://doi.org/10.1016/j.respol.2012.09.007.

Phillips, P.C.B. and Moon, H.R., 1999. Linear regression limit theory for nonstationary panel data. Econometrica, 67, pp.1057-1111. https://doi.org/10.1111/1468-0262.00070.

Soh, P.H. and Subramanian, A.M., 2014. When do firms benefit from universityindustry R\&D collaborations? The implications of firm R\&D focus on scientific research and technological recombination. Journal of Business Venturing, 29(6), pp.807-821. https://doi.org/10.1016/j.jbusvent.2013.11.001.

Solow, R., 1957. Technical change and the aggregate production function. Review of Economics and. Statistics, 39, pp. 312-320.

Stankevice, I. and Jucevicius, G., 2013. Institutional vs. sectoral dimension of innovation strategies of firms. Technological and Economic Development of Economy, 19(sup1), pp.360-382. https://doi.org/10.3846/20294913.2013.879752.

Stephan, P.E., Gurmu, S., Sumell, A.J. and Black, G., 2007. Who's patenting in the university? Evidence from the survey of doctorate recipients. Economics of Innovation and New Technology, 16(2), pp.71-99. https://doi.org/10.1080/10438590600982806.

Tether, B.S., 2002. Who co-operates for innovation, and why: An empirical analysis. Research Policy, 31(6), pp.947-967.

Thomas, V.J., Sharma, S. and Jain, S.K., 2011. Using patents and publications to assess R\&D efficiency in the states of the USA. World Patent Information, 33(1), pp.4-10. https://doi.org/10.1016/S0048-7333(01)00172-X.

Veugelers, R., Callaert, J., Song, X. and Van Looy, B., 2012. The participation of universities in technology development: do creation and use coincide? An empirical investigation on the level of national innovation systems. Economics of Innovation and New Technology, 21(5-6), pp.445-472. https://doi.org/10.1080/10438599.2012.656527.

Zachariadis, M., 2003. R\&D Innovation and technological progress: A test of the Schumpeterian framework without scale effects. Canadian Journal of Economics, 36(3), pp.566-586. https://doi.org/10.1111/1540-5982.t01-2-00003. 


\section{APPENDIX}

The results of panel unit root tests

\begin{tabular}{|c|c|c|c|c|c|}
\hline & \multicolumn{5}{|c|}{ Null Hypothesis: non-stationarity } \\
\hline & LLC test & Breitung & IPS test & ADF test & PP test \\
\hline SciArticles_on_pop - intercept & 2.9 & & 5.52 & 106.2 & 145.5 \\
\hline $\begin{array}{l}\text { SciArticles_on_pop - intercept \& } \\
\text { trend }\end{array}$ & -1.6 & 6.1 & 0.4 & $159.1 * *$ & $170.9 * * *$ \\
\hline$\Delta$ SciArticles_on_pop - intercept & $-18.4 * * *$ & $-18.9 * * *$ & $-17.7 * * *$ & $602.1 * * *$ & $800.4^{* * *}$ \\
\hline $\begin{array}{l}\Delta \text { SciArticles_on_pop - intercept \& } \\
\text { trend }\end{array}$ & $-18.3 * * *$ & $-4.3^{* * *}$ & $-16.8 * * *$ & $501.9 * * *$ & $743.2 * * *$ \\
\hline HighTech export - intercept \& trend & $-5.1 * * *$ & 4.8 & -1.4 & $157.1 * *$ & 108.12 \\
\hline $\begin{array}{l}\Delta \text { HighTech export - intercept \& } \\
\text { trend }\end{array}$ & $-17.9 * * *$ & $-11.4 * * *$ & $-15.4 * * *$ & $438.2 * * *$ & $616.2 * * *$ \\
\hline Patents_on_pop - intercept & -2.9 & & $-0.1 * * *$ & $237.7 *$ & $338.81 *$ \\
\hline Patents_on_pop - intercept $\&$ trend & 0.5 & 6.03 & $-3.6 * * *$ & $226.4 * * *$ & $252.8 * * *$ \\
\hline$\Delta$ Patents_on_pop - intercept & $-20.9 * * *$ & & $-21.3 * * *$ & $786.0 * * *$ & $1863.2 * * *$ \\
\hline$\Delta$ Patents_on_pop - intercept $\&$ trend & $-35.2 * * *$ & $-4.7 * * *$ & $-21.9 * * *$ & $517.4 * * *$ & $767.0 * * *$ \\
\hline GDP per capita - intercept \& trend & -0.3 & 6.0 & 1.9 & 109.9 & 70.6 \\
\hline$\Delta$ GDP per capita - intercept $\&$ trend & $-13.7 * * *$ & $3.9 * * *$ & $-10.3 * * *$ & $338.4 * * *$ & $391.3 * * *$ \\
\hline FDI net inflow - intercept & $-8.5 * * *$ & & $-11.3 * * *$ & $351.9 * * *$ & $335.8 * * *$ \\
\hline FDI net inflow - intercept \& trend & $-8.5 * * *$ & $7.1 * * *$ & $-8.7 * * *$ & $277.9 * * *$ & $298.0 * * *$ \\
\hline
\end{tabular}

\section{ABOUT AUTHORS}

Prof. Marta Orviská is a professor of finance at Matej Bel University in Banska Bystrica, Slovakia, and is one of the most frequently cited economists in the country. Her research interests are macroeconomics and public finance, tax policy and tax evasion, standardisation, and attitudes to multinational institutions and new technologies. She has held several positions in national and international projects in these areas and has published a large number of papers in leading academic journals including Nano Today, International Journal of Social Robotics and Transportation Research Part A: Policy and Practice. The author can be contacted at marta.orviska@umb.sk. 
Ing. Jan Huňady, PhD. is an assistant professor at Faculty of Economics, Matej Bel University in Banska Bystrica, Slovakia. His research interests focus on public finance, taxation, public sector and public institutions, higher education, innovation and new technologies. He has also expertise in econometrics particularly panel data and time series analysis. He has published a number of papers in journals such as Economia Politica, Transportation Research Part A: Policy and Practice, International Journal of Social Robotics, Engineering economics and Prague Economic Papers. The author can be contacted at jan.hunady@umb.sk.

doc. Ing. Peter Pisár, PhD. is an associate professor of finance, banking and investment at Faculty of Economics, Matej Bel University in Banska Bystrica, Slovakia. He has been the Head of Department of Finance and Accounting since 2015. His research is focused on European public finances, especially innovation, innovative financing and the evaluation of regional policy and public expenditure programs. In practice, he is also a consultant for the development and implementation of projects supported by EU funds and is particularly concerned with public policies supporting innovation. The author can be contacted at peter.pisar@umb.sk.

Prof. John Hudson ${ }^{\dagger}$ was a professor of Economics at University of Bath until his sudden death in July 2018. He has advised the Departments for Trade and Industry and International Development as well as the SouthWest Regional Development Agency, all in the UK. His research has been presented to the OECD and he has been a keynote speaker at conferences throughout Europe. A past vicepresident of the European Academy for Standardization, he has also been a visiting professor at The University of Economics in Bratislava and Cerdi, University of Auvergne. His research spans the whole of economics and much of the social sciences and has been published in approximately 100 papers in leading economics and science journals.

(C) 2019 by the authors. Submitted for possible open access publication under the terms and conditions of the Creative Commons Attribution (CC-BY) license (http://creativecommons.org/licenses/by/4.0/). 